


\title{
1 nuevos aires para la democracia
}

\author{
Augusto Serrano López
}

De argonautas y caminantes hablaba yo en el número anterior de Población y D esarrollo para resaltar ese lado de la condición humana que se suele subordinar al de los poblamientos, sin percibir así que somos desde nuestro nacimiento "gente en camino", emigrantes por naturaleza y seres, en fin, insatisfechos que buscan sin cesar la patria soñada que, por cierto y a decir de E. Bloch, habría que buscarla en el lugar donde aún nadie estuvo.

Caminantes por una Tierra que, hasta hace pocos años si se mira desde la perspectiva de la especie humana, nos venía demasiado grande y con multitud de lugares inéditos, paraísos por nadie hollados, valles y crestas montañosas a las que sólo el águila se había asomado, ríos de corrientes vírgenes, aguas, en fin, y aires que de puros inspiraron a pintores y poetas e hicieron las veces de anzuel os para los más bizarros exploradores.

Pero todo o casi todo esto se nos fue para siempre. A lomos de las ciencias modernasy de las tecnologías más potentes e impul sados por un tiempo moderno desenfrenado, al ser humano le entró hace apenas cien años una furia inmensa por producir y por transformar, por consumir y por derrochar, generando una sobrenatural eza que de virgen ya nada tiene y que, superpuesta arrolladoramente sobre la primera y sobre la segunda, modifica modos de vivir y de ser, de hechos y de posibilidades. $\mathrm{H}$ emos trazado puentes para que los ríos no nos separen, túneles para burlar las montañas, pasajes submarinos para tejer el planeta con redes de una densidad increíble; volamos más rápido que las aves, nos zambullimos en las simas más profundas de los océanos y ya no queda ningún ochomil en el H imalaya que no haya sido coronado por multitud de expediciones. Hemos transformado el clima y somos, para nuestra desgracia, los "guardianes de la bomba" (J. P. Sartre) desde que, aprendices de brujo, sacamos de la botella el saber sobre la desintegración atómica y hemos de convivir, nos guste o no, con desechos que sobrepasan por sus efectos la escala humana.

A hí estamos llegando, aunque no creo que la humanidad comience ya a tomar plena conciencia de ello.

Q uiere decir que, desde hace apenas setenta años, el ser humano ha cambiado rotunda e irreversiblemente su relación con la Tierra.

A hora, caminar y poblar sobre la Tierra no es la misma actividad que tuvieron que desarrollar nuestros ancestros para salir de las sabanas africanas ni para cubrir el mapa de A mérica desde el estrecho de Bering a la Patagonia. C aminar y poblar, emigrar y asentarse resultan hechos sobre una cuadrícula previamente preparada por los seres humanos, determinada por la praxis más potente que ha conocido la historia de nuestra especie. No queda lugar ya para nuevos colones de la geografía, como no sea para explorar las densas selvas de las entretelas del al ma humana a la búsqueda de al gún indicio de inteligencia y prudencia, de solidaridad y tolerancia.

Pero, ¿habrán tomado nota de esto las disciplinas científicas: esas ciencias modernas que, a decir de M. H eidegger, constituyen el faktum de nuestro tiempo? ¿Y habrá tomado nota de esta tran sformación la Demografía; la ciencia moderna que supuestamente grafica y le sigue los pasos a este caminante eterno?

$\mathrm{N}$ ueva tierra y nuevos cielos se esperaban como llegada a la patria prometida o soñada desde los mitos y desde las religiones, desde las teorías más atrevidas y, claro está, desde las utopías. De modo que las leyes de población, las constantes encontradas después de tanto estudio acaecen ahora sobre una superficie previamente modificada que, se quiera o no, predetermina lo que se hace y cómo se hace y obliga a las ciencias, incluida la Demografía, a "internalizar" como asunto decisivo las nuevas circunstancias, para que su discurso 
sea vivo y no simple recuerdo de lo que fue un día.

Y que se entienda bien: no se le está pidiendo a la Demografía que se haga ecológica por aquello de las modas verdes del momento.

Tanto o más se le pide a la Ecología que dé el salto definitivo para convertirse en ciencia y desarrolle esa dimensión social sin la que aparece huérfana y desalmada. D emografía y Ecología deben acercar sus cierres categoriales, intersectar sus intereses para que ambas salgan beneficiadas y comiencen a hablar del ser humano concreto: el que ha modificado de tal manera su medio vital que vive en una natural eza casi total mente humanizada.

A la Tierra (con mayúscula) le ha nacido un ser que no cesa de generar condiciones inéditas tanto físicas como sociales y que se venía valiendo hasta ahora de unas ciencias que deben ponerse a tono con los nuevos ritmos y con los nuevos desafíos para la vida. 